\title{
The Adversity on Establishing Places of Worship: Has Religious Freedom Failed in Indonesia?
}

\author{
Ridwan Arifin ${ }^{1 *}$, Hanif Helmi ${ }^{2}$, Ngaboawaji Daniel Nte ${ }^{3}$, Waspiah ${ }^{4}$, Dian \\ Latifiani $^{5}$
}

\footnotetext{
1,2,4,5 Faculty of Law, Universitas Negeri Semarang, Semarang, 50229, Indonesia

${ }^{3}$ Department of Intelligence and Security Studies, Novena University, Nigeria

* Corresponding author: ridwan.arifin@mail.unnes.ac.id
}

\begin{tabular}{|c|c|}
\hline Article & Abstract \\
\hline $\begin{array}{l}\text { Keywords: } \\
\text { Human rights; religious } \\
\text { freedom; Indonesian } \\
\text { religious policy; Security } \\
\text { studies }\end{array}$ & $\begin{array}{l}\text { Religious freedom has various interpretations in practice, although the } \\
\text { rule of law regulates this right. In many cases, freedom of religion is } \\
\text { closely related to human rights and security studies, however, not } \\
\text { infrequently, the cases intersect with political policies. This paper aims } \\
\text { to analyze various cases regarding religious freedom in Indonesia } \\
\text { concerning human rights. This paper examines various phenomena } \\
\text { related to difficulties and establishing places of worship, especially for } \\
\text { certain groups in Indonesia in various policies and legal regulations in } \\
\text { Indonesia. The method used for this research is non-empirical } \\
\text { research. All data dan information analyzed come up from various } \\
\text { previous research. This paper found and underlined that debates on } \\
\text { the relativity of human rights often lead to different perceptions in } \\
\text { human rights standards. Various laws relating to communities of } \\
\text { places of worship, in many cases and considered by many experts to } \\
\text { violate the basic principles of human rights. This paper also } \\
\text { emphasized that the fulfillment of human rights in Indonesia } \\
\text { concerning religious freedom cannot be separated from historical, } \\
\text { sociological, and cultural factors of the Indonesian people themselves. }\end{array}$ \\
\hline
\end{tabular}

(C)2021; This is an Open Acces Research distributed under the term of the Creative Commons Attribution Licenses (https://Creativecommons.org/licences/by/4.0), which permits unrestricted use, distribution, and reproduction in any medium, provided the original works is properly cited.

\section{INTRODUCTION}

Pluralism in Indonesian society is a noteworthy aspect that is impossible to ignore or even to be considered nil. The population of Indonesia, which is so large and growing, is also not a new phenomenon, given the fact that Indonesia's geographic area has a large area and is in a fertile location and not to mention strategic, making 
population growth and its diversity a commonplace that should be understood. In history, human civilization in the territory of Indonesia, which was formerly known as Nusantara, also deserves to be underlined as the cause of Indonesia's plurality today.

The strategic area of Indonesia has invited many traders in the past to moor in this archipelago, which inadvertently has also brought new influences in socio-cultural life as well as in private religious life. Traders from India and China brought the teachings of Hinduism and Buddhism, which gave birth to several great civilizations such as Majapabit and Sriwijaya in the archipelago. Then traders from the Middle East and the Persian Plain brought Islamic teachings which until now have become the predominant religion in modern Indonesia. Likewise, the arrival of the Europeans with their colonial power succeeded in preaching Christianity, which is now the minority religion with the most significant number of adherents.

However, this background of pluralism that has been embedded since the past has not made Indonesia a country that is smoothly enlivened with tolerance and respect for differences. The devide et impera politics brought by the colonial rulers and the sentiments that were born thereof continue to exist today. This negative habit can be proven by the existence of anti-Chinese sentiments that have started with the Geger Pacinan tragedy or history recorded it as the 1740 Batavia Massacre, a pogrom against ethnic Chinese (Blussé, 2016). This racial sentiment continues to flourish and be nurtured and seems like it something normal, stereotyping the bad influence of the Chinese ethnic group and the idea that they intend to drain the country's wealth for the sake of their homeland in Mainland China continues to be instilled in society so that they grow up with hatred, these sentiments are the main cause of some pogrom against Chinese ethnic in 1965-66 and 1998 (Heidhues, 2012).

The founders of the Republic of Indonesia have seen the reality of the plurality of the Indonesian people, and with that, they are also aware of all opportunities for the division as a negative impact it will bring (Putri, 2011). History has also recorded heated debates in the efforts to prepare for Indonesian independence. The debate refers to what should be the basis for the establishment of the Indonesian state. Muslim scholars insist on the use of the term Sharia and its practices because the majority of Indonesia's population adheres to Islam, this is rejected by non-Muslim groups who feel they are not represented (Basyir, 1993). Although in the end this was resolved with a cool head and an agreement to use a more neutral and impartial term, it is sufficient to note that the role of religion is vital for Indonesians and the dispute over it is such a sensitive issue that could erupt conflicts at any time.

The Indonesian government, based on this premise, then with all its efforts to facilitate and accommodate the diversity of these religious communities. Even the country's slogan Bhinneka Tunggal Ika (Unity in Diversity) continues to be echoed to support national integration. Various state attributes are also made by prioritizing unity and nondiscriminatory aspects, Pancasila for example, calls "Belief in One True God," 
as its first point - which is neutral from any particular religious influence, but still concludes that belief in God is the basis the state - besides that, the 1945 constitution also mentions a lot about freedom of religion and worship, referring to it as part of human rights, which are highly respected in the Republic of Indonesia.

Some of the basic legal provisions that state the right to freedom of religion in Indonesia include:

1. Article 28E p. (1) 1945 Constitution:

"Every person is free to adhere to a religion and worship accordingly to their religion..."

2. Article 28E p. (2) 1945 Constitution:

"Every person has the right to freedom of beliefs"

3. Article 28I p. (1) 1945 Constitution:

"Right to adhere to a religion is a part of Human Rights"

4. Article 29 p. (2) 1945 Constitution:

"The State guaranteed the freedom of religious beliefs for each of its citizens"

Nevertheless, the state only recognized 6 major religions: Islam, Roman Catholic, Protestantism (under the label "Christian"), Hinduism, Buddhism, and Confucianism (Kong $\mathrm{Hu} \mathrm{Cbu}$ ) as official religions of the Republic of Indonesia. These "official" religions are accommodated by the Ministry of Religious Affairs and are having clear legal rights and protections. Meanwhile so, shamanism and other folk religions/beliefs are not categorized as religion and are accommodated by the Ministry of Education and Culture (Z. Aditya \& Al-Fatih, 2017; Islam, 2020; Pratiwi, 2019; Putri, 2011; Rotaru, 2017). And as a religious practice is guaranteed in the constitution, the Human Rights Act No.39 of 1999 stipulated it as one of the fundamental rights (Pratiwi, 2019). Furthermore, Ratification of the International Covenant on Civil and Political Rights Act No.12 of 2005 also described aspects of worship rituals - a place of worship as an integral part - thus any religious practice including the establishment of a place of worship is a part of the manifestation of religious rights stipulated on the constitution and the Human Rights Act (Adon, 2018; Hartani \& Nulhaqim, 2020; Hutabarat, 2017; Wijayanto et al., 2020).

The religious heterogeneity of the Indonesian community brings an all-time high conflict potential (Pangestu, 2013), especially in the aspect of religious preaching and ceremonial worship, both are mostly done in a house of worship (mosques, churches, temples, etc.) which made it gain a suspicion as a place to reach and make people convert to other religion. This suspicion developed into an issue about "Christianization," or "Islamization" and resulting in a conflict. The earliest recorded tragedy on this issue is in 1967, where an undung - undung (chapel) was burnt down by the majority of Muslim citizens in a rural village in Meulaboh, Western Aceh who regarded the existence of the chapel as inappropriate to the socio-psychological conditions of the community (Muchtar et al., 2010). 
After the 1967 Meulaboh tragedy, numerous cases of conflicts regarding a controversial place of worship sprung up in some conservative regions throughout the country. These conflicts then came to the sense of the Minister of Religious Affairs and the Minister of Home Affairs as a horizontal conflict slowly smoldering and endangering the integrity. The Ministers then agreed to issue the Surat Keputusan Bersama 2 Menteri - Joint Regulation - known as SKB 2 in 1969 to prevent any further skirmishes between religious communities on the establishment of places of worship. The regulation was renewed in Peraturan Bersama 2 Menteri - Joint Regulation - No. 9 and 8 of 2006 further known as PBM.

The PBM was issued to complement some particulars things that are not regulated in the previous version of the regulation (SKB). Nevertheless, it does not mean that the regulation is perfect, on the contrary, this PBM provokes several new issues that can now be categorized as acts of intolerance. Some of the special regulations contained in this PBM include requiring the conformity of building functions with what is stated in the land certificate and Building Construction Permit (IMB), making the conversion of a building into a place of worship very difficult. Also, the conversion of the building function to become a place of worship, or the construction of a new place of worship must obtain the approval of at least 60 residents with an active Identity Card (Steven et al., 2015) - also the approval of the 90 congregation members if the designated place of worship is a church (Hutabarat, 2017).

This regulation was not implemented successfully, because parties who would ask for permission would usually be faced with an awkward position. If the party did what the regulation requested accordingly (asked for approval manually from 60 residents), not only would it take a long time the expected approval could not be obtained because of the suspicion. Meanwhile, if it is carried out through certain "officers" who are more time-efficient, it will usually lead to mass demonstrations under the auspices of certain community organizations that call the construction of places of worship illegal (Crysdian, 2015).

Even when applications for establishment activities are official and permitted both by the government and by residents following the criteria required by PBM to build places of worship, demonstrations often occur by residents - who are not even residents, but because of the connection of one religious organization which rejects the construction of these places of worship - and even some acts of anarchism such as vandalism, looting, and even evictions.

Among the examples of the most serious cases of the ineffectiveness of this PBM are:

1. Vandalism and arson against the St. Albert's Catholic Church in Harapan Indah, Bekasi. Which even though it has received government permission and fulfills the special requirements of PBM honestly. Previously, the construction of this church was also subject to rejection by residents (Muchtar et al., 2010). 
2. Annulment of the building permit for the GKI Yasmin church, Bogor on charges of falsifying the signature of the agreement (Pratiwi, 2019).

3. Sealing by the local government and a demonstration by residents of the HKBP Filadelfia church building, Tambun, Bekasi which has met the prerequisites set by PBM (Crouch, 2010).

4. The burning of the Misbahul Huda Shi'ite Islamic boarding school in Sampang, Madura, was allegedly due to slander from fanatical Islamic schools under the antiShia sentiment. As a result, the government had to relocate the Shia population to a safer place (Mu’ti \& Burhani, 2019).

In some of the cases listed it can be seen that the gap in the shortcomings of this PBM is also used as a way to make it difficult, cancel or prevent the establishment of places of worship — especially for religious minorities—also indirectly injures the right to freedom to practice religion according to beliefs as contained in the provisions of the constitution. Apart from these cases, the National Commission on Human Rights of the Republic of Indonesia also continues to record many cases of refusal of places of worship to date, even when the latest relevant legal provisions are still in effect (Pratiwi, 2019). This research contributes to increasing understanding of the protection of human rights and the dialectic of religious freedom. This research also contributes to efforts to improve regulations relating to the protection of civil society concerning the rights of worship.

\section{METHOD}

Various cases related to religious freedom in this study were obtained from various previous studies, this research is not field research, so the author only analyzes existing cases using various theories of law and justice. In the legal research method (Ali, 2020; Ali et al., 2017; McConville, 2017; Watkins \& Burton, 2017), this study compares and analyzes several articles related to religious freedom, related legal rules, related international conventions, and some expert opinions obtained from various media, both print and online.

\section{RESULT AND DISCUSSION}

\section{Role of Religion in Indonesia}

When we discuss the role of religion in Indonesia, the easiest way for us to make a basis is to remember the past. The thought patterns of the Indonesian people at that time which were thick with customs and traditions were perhaps the most prominent, but if we uncover the veil of customs and traditions, the influence of religion is extensive, religion-centrism is comprehensive in the development of the mindset of Indonesian society to this day. National History which is now being taught to students also explicitly classifies the era in the development of the Indonesian archipelago by mentioning the Hindu-Buddhist Kingdom Period and the Islamic Kingdom Period, 
which proves that the influence of these religions is very thick in the creation and socio-cultural patterns of modern Indonesian society.

Several ancient kingdoms were also almost entirely religious: Majapabit adhered to Hinduism as the state religion; Sriwijaya adheres to Buddhism as the state religion; Samudera Pasai, Melaka, Mataram, and Makassar all adhere to Islam as the state religion; and Larantuka, who adheres to Roman Catholicism as the state religion. With full feudal power which was also held by these rulers, the culture of the people was also regulated as they wanted, which was also full of the teachings of their religion.

The culture of the people who are influenced by these religions then also opens the way of thinking of the community, by creating acculturation and assimilation between the original culture of the archipelago and these religions. For example, in the tradition and culture sector, the Javanese, Sundanese, and Balinese tribes were strongly influenced by Hindu-Buddhist culture from the Indian sub-continent and the Indochina peninsula, - even though Javanese and Sundanese are now predominantly Muslim - the ethnic groups who inhabit Sumatra are strongly influenced with the culture and teachings of Islam from the Middle East and Persia, while several ethnic groups on the island of Kalimantan, Sulawesi, as well as the Nusa Tenggara Islands were heavily influenced by Christian and Catholic teachings preached by Europeans Spanish, Portuguese, and Dutch—who had visited and controlled the region for a considerable period.

It is enough that we discuss the role of religion in the classical period of Indonesia, then we will briefly discuss the role of religion in the Dutch colonial period. Since the beginning of Dutch colonization in the period of the Dutch East Indies Company (VOC), the Dutch have avoided spiritual-religious friction with the Indigenous people (Basyir, 1993). This can be proven by the absence of coercion to adopt Dutch law after the application of the Napoleonic Law in the Dutch East Indies in 1847. GovernorGeneral Jan Jacob Rochussen, who was sovereign at that time, declared the application of customary law to indigenous communities, and the application of Islamic law applied to Natives who are predominantly Muslim. The formation of the Religious Court (Godsdienstige Rechtspraak) in 1882 also strengthened the role of religion (Wahyudi, 2016)—specifically Islam—in this period.

Even though the Dutch colonial government was concerned about the political potential that could arise from the Conservative Muslims, the colonial government guaranteed freedom of worship and religion - limited to religious activities and education and still prohibited religious activities that were accompanied by political elements - in the Regeeringsreglement article 119 of 1854. The prohibition of Christian missionary activities without the permission of the parliament and the governorgeneral, to prevent any conflicts with the Muslim communities (Haris, 2017). From this period, the state law and administration began to make legal arrangements for religion and its adherents (Haris, 2017). 
During the military rule of the Japanese empire, the role of religion was initiated as an opportunity to seek sympathy and support from the indigenous Indonesian people. Islamic religious activities have the freedom to be carried out, whether purely divine, educational, economic, socio-cultural, even accompanied by political elements provided that they praise the power of Dai Nippon and support the Japanese Military Government. The exercise of this right is accompanied by direct and tight supervision of the Japanese Military Government.

But in this period, there were also clear examples of restrictions on religious activities in Indonesia, the anti-Chinese sentiment that was also brought by Japan after the Manchurian invasion was also implemented in Indonesia, this condition made ethnic Chinese the scapegoats. Many Chinese women were turned into comfort women (Jugun-ianfu - 従軍慰安婦), confiscation of their property, burning of Chinatowns, and looting and forcibly closing Chinese temples were rampant in big cities (Heidhues, 2012). Besides, strict supervision of existing churches was also carried out - with exceptions for churches that were affiliated with Roman Catholicism; Japan and Italy (influenced the Vatican at that time) had strong diplomatic ties because they fought on the same side - based on the thought of the church and Christianity as a Western religion, not to mention most of the clerics are mostly Europeans or Eurasians that could carry out anti-Japanese messages to the people and erupts such insurgency (Haris, 2017).

A few days before the proclamation of independence and the establishment of the Republic of Indonesia, several debates emerged between the country's founding figures who were members of the Indonesian Independence Preparatory Investigation Agency (BPUPKI). In general, this debate is related to the basis of the Indonesian state, representatives of conservative Muslim circles uphold Sharia as the basis of the state, on the pretext that Indonesia's population is predominantly Muslim ( $\mathrm{Z}$ Firma Aditya \& Al-Fatih, 2017). This idea is of course rejected by representatives of nonMuslims, who state that the use of sharia is the same as not representing the Indonesian nation that is not a Muslim. Until finally it was agreed that the basis of the Republic of Indonesia is Pancasila, which was initiated by Ir. Soekarno on June 1, 1945.

Meanwhile, in the Jakarta Charter, which was issued to serve as the Preamble of the country's basic constitution, the first point reads "Divinity, with the obligation to carry out Islamic law for its adherents." This term was later changed to "God Almighty," at the suggestion of A. A. Maramis who had consulted with T. M. Hassan, K. Singodimedjo, and K. B. Hadikoesoemo, these three Muslim figures also voiced the same suggestion to Moh. Hatta, with considerations for the sake of integration and unity of the nation and state (Basyir, 1993). Looking at this narrative, many sources will say that Indonesia is still affiliated with Islam, even though it does not include this provision in any of the state attributes. However, the 4th president of the Republic of 
Indonesia K. H. Abdurrahman Wahid emphasized that Indonesia is not a religiousaffiliated state (Haris, 2017).

Talks about the existence of God as the foundation of the state emerged from figures who presented their ideas to become the basis of the State (Kim, 1998). Soekarno said that the state must be Belief in God, so that the Indonesian nation should have faith and obedience to God, in this idea Soekarno used the term "God," he did not mention the name of God in a specific religious designation, he also added that the Indonesian nation should believe in God without a religious affiliation faith and practice respect between adherents of different religions (Hamayotsu, 2013). Without a particular religion mentioned in the idea - which was later accepted - then the Republic of Indonesia does not consider itself a religious state.

Every state government in the world places religion and divinity in different status and roles, in general, the status of religion in the state creates two classifications of states that can be distinguished as: the secular states (separating the church and religious role to the state and government), and the religious-affiliated states (adhering to certain religious teachings and implementing their practices in the lives of citizens and the running of government) (Seo, 2012). Countries on the continent of Europe normally adhere to a secular system - except for Great Britain where the ruling Monarch also has the status of the head of the Anglican Church; Greece which grants special rights to the Eastern Orthodox Church Authority; and the Vatican, the holy seat of the Catholic Papacy and the center of Catholic jurisdiction in the world - while most countries in Asia and Africa generally place a certain religion as the official state religion - except for the Republic of Korea, Japan, and Singapore which explicitly stated their countries as secular states (Seo, 2012), and the People's Republic of China which forbids religion and practices state atheism (Situmorang, 2019).

The Republic of Indonesia is one of the few countries in the world which uniquely does not place itself in the categories described above (Crouch, 2009). From its demographic background, Muslim-majority Indonesia has not followed in the footsteps of Pakistan, Iran, Saudi Arabia, or its closest neighbors Brunei and Malaysia in recognizing Islam as the state religion (Crouch, 2009). However, Indonesia also did not claim that this country adheres to absolute secularism, such as Turkey, Albania, and Azerbaijan. Simply, The Republic of Indonesia is neither a religion-affiliated state nor a secular state for that reason.

This condition is a big question that is still frequently discussed in various studies and discussions in national forums regarding the position of religion. Some fanatic groups say that Indonesia is an Islamic country, and many relate the foundations of the state with Islamic values which they call implied statements, that Indonesia is an Islamic state.

Whereas in fact among the people, the state does not even have regulations that oblige every citizen to obey worship, even in contemporary terms, the conversion is 
something that is not prohibited by law as in Islamic countries - although usually, it will cause social controversy - and people whom a change of religion must submit a residence request to the court and the civil registration and population service office where he is domiciled (Hefner, 2013). Religious life is completely personal in nature, regarding a person's will to be obedient in his practice of religion, or to be fully agnostic and irreligious is a right reserved for every citizen, and there are no provisions or legal regulations that oblige or prohibit it. Nevertheless, on the other hand, the state still provides some guidance and services in religious life.

By looking at these conditions, Indonesia places religion and worship practices not as benchmarks for spirituality, but just as a requirement in the records of state administration (Seo, 2012). Even in several recent regulations, such as Citizenship Registration Act No. 24 of 2013, it allows blanking of the religion column on the identity card for those whose religion is not included in the 6 official religions in Indonesia (Marshall, 2018).

This fact concluded that the Republic of Indonesia is closer to secularism as initiated by Ataturk in Turkey, or similar to what is called laïcité in France, an understanding that states that religious life is a private matter and all practices, education, and religious law (Bowen, 2010). All of them are equally sheltered and controlled by the state. The only difference is that the Government of the Republic of Indonesia still recognizes Islamic Law and provides a Religious Court for Muslim communities who resolve their civil cases using Islamic Law (Bowen, 2010). The Indonesian government also allows its provincial government to adopt conservatism and the influence of certain religions if the population is more homogeneous in terms of diversity.

Even so, the term secularism is still considered taboo in the mindset of Indonesian society. Many fanatic Muslim groups have accused the efforts of secularizing the state as an attempt of aggression by Christian groups or radical thought rather than antireligious groups. This condition is also the reason why most irreligious Indonesian people do not call themselves agnostic to prevent themselves from being considered anti-religious or even communist-which is strictly prohibited in Indonesia.

\section{Religious Freedom and Its Legal Basis}

Freedom in religion is fully guaranteed by the Indonesian government according to the legal provisions contained in the 1945 Constitution. The Indonesian government explicitly states that "every citizen is free to adhere to a religion and carry out worship following the teachings of his religion", and "every citizen has the right to freedom of belief", in Article 28E. Furthermore, Article 29 also stated that the state guarantees freedom of religion for every citizen.

According to the history of its development, the journey of religious freedom in Indonesia is divided into several chapters: in the Era of Old Order; New Order; and 
Reformation Era. Thus, to be able to characterize the religious freedom legal development, this chapter will be separated into three sub-chapters according to their respective eras.

a. Old Order Era (1945-1965)

Religious freedom in the Old Order era was to take a stake in religious freedom that had existed in the Dutch colonial era - when Indonesia was a part of Dutch dominion with the name Dutch East Indies - while similar to the colonial period, the government in the Old Order era did not stipulate religious laws related to religion certain, this is natural because in that era the Indonesian government was influenced by 3 major political ideologies: Nationalism, Islamism, and Communism. This made religious affiliation is subsequently not a priority.

Only through the Explanation of Freedom of Religion Act No.1 PNPS / 1965, which specifically mentions the religions adhered to by the Indonesian people, namely: Islam, Christianity, Catholicism, Hinduism, Buddhism, and Confucianism. However, this law does not provide more exclusivity and privileges than other religions (Kim, 1998). This also does not imply that other religions are prohibited from being practiced in Indonesia. Religions other than those stipulated are permitted to be followed and expressed frontally as long as they do not violate the boundaries stipulated by applicable law, as stipulated by Article 29 (2) of the Constitution (Christianto, 2013).

The President of the Republic of Indonesia at that time, Ir. Soekarno often actively voiced his views on belief in God, as he had established in Pancasila, namely "Believing in One Supreme God." So that the Indonesian nation's mindset was formed at that time to see God as a single entity that they must believe in, as an entity they worship to ask for something regardless of the type and form of religion. However, it does not mean that this period has succeeded in upholding religious freedom. Before the issuance of the Freedom of Religion Act No.1 PNPS/1965, only Muslim and Christian communities could enjoy the right to have a religion perfectly, the state recognized both as official religions since Indonesia's independence. Problems had arisen for the Hindu community on the island of Bali, the Buddhist and Confucian communities. The mention of the term "One true God," in Pancasila at that time was interpreted as the necessity to have only one God. Whereas Hinduism is a polytheistic religion with many deities, Buddhism is a non-theism religion that does not recognize the system of entity-worshipping, and Confucianism which is a belief that adheres to the ancestral worship system (Mu'ti \& Burhani, 2019).

To meet these criteria, Indonesian Hindus call Sang Hyang Widhi their "One" God — which is non-existent in any other Hindu teachings elsewhere out Indonesia,-First Indonesian Buddhist Bhikku Ashin Jinarakkhita mentions that Indonesian Buddhism has Sang Hyang Adhi Buddha as its God-which gains controversy among international Buddhist clerics, and the Confucian community calls Thian their One God. After all of this, other unlisted criteria categorize a belief as a religion, namely that it had to has 
scripture and a prophet (Mu'ti \& Burhani, 2019). Hinduism and Buddhism succeeded in gaining religious status in 1962, while Confucianism in 1965 (Seo, 2012).

b. New Order Era (1966-1998)

Inclusiveness inside the Explanation of Freedom of Religion Act No.1 PNPS / 1965 has been changed since the beginning of the New Order era (Kim, 1998). The religions mentioned in this law are used as the basis that only these religions are recognized by the Indonesian government, and this forms a public perception that only these religions can be adhered to and carried out their religious activities among Indonesians. This was also reduced because Confucianism had lost its status since 1967 through Presidential Instruction No. 14/1967 concerning the Prohibition of Chinese Religions, Beliefs, and Customs, this constitutes injustice and harm for ethnic Chinese only because of state politics which did not occur to the other five religions (Muktiono, 2012) — strong anti-Chinese sentiment as a result of the dissolution of the Indonesian Communist Party which was accused of attempting to commit coup in 1965, this sentiment was born over allegations of ethnic Chinese proximity to Communist China's Government (Mu'ti \& Burhani, 2019).

The anti-Communism ideology promoted by the New Order regime caused considerable conflict throughout the country. The pogrom and genocide against the so-called PKI "stooges" were rampant throughout Indonesia, the targets of this pogrom included ethnic Chinese and Abangan Javanese, those with socialist and secular views were also became victims. Not only that, even someone who once voted for the Indonesian Communist Party in a general election, would be labeled as guilty as supporting communism.

Not only that, people who embraced traditional religions that were not recognized by the government such as the Parmalim, Kaharingan, and Wiwitan religions were also targeted by Muslim organizations members who helped the military carry out this "purging".

As a result of this pogrom, many ethnic Chinese and adherents of traditional religions converted to Christianity, and because of this, the sentiment towards Christianity has intensified. The first tragedy that erupted in 1967 when a church was burned in Meulaboh Aceh, and a storming of a church in Makassar on allegations of attempts to Christianization in Aceh and defamation of religion in Makassar, this incident later became the cause of the issuance of SKB 2 regulation on the construction of houses of worship in Indonesia (Muchtar et al., 2010).

Several policies that followed seemed to attempt to eradicate religious diversity in Indonesia. At the time, there are 22 indigenous traditional Indonesian beliefs, almost all of which are ancient religions that existed before religions such as Hinduism, Buddhism, Islam, and Christianity had not yet entered Indonesia. These customary beliefs are not recognized by the state and cannot be stated on the Identity Card neither 
there were administrative service and religious protection, nor even legal protection for adherents of these beliefs. The New Order government only then brought indigenous religions conservation under the auspices of the Ministry of Tourism-not the Ministry of Religious Affairs-in 1992 (Putri, 2011).

The era of the New Order government was made a new hope by Muslim politicians at that time to add to the role of Sharia and Islamic law in their involvement in government. However, President Suharto, with his unlimited and authoritarian state power, actually saw the negative potential that might arise if the role of sharia and Islam was left extensively. So that the government at that time with all its efforts tried to close all certain Islamic political thoughts that were not following the ideals brought by the government at that time. The government then also tried to make Islam only a socio-cultural element and minimize its role in politics (Hefner, 2013).

c. Post-New Order - Reformation Era

After the fall of Suharto as the aftermath of mass demonstrations in 1998 which became known as the Reformation era, the government system in the Republic of Indonesia changed in a very drastic way, decentralization in the administrative area was enforced, as well as many changes in the institutional layer of government - including in the field of constituencies. In terms of religious regulation, advocacy and political thinking about Islam and Sharia, which had been extensively restrained, began to emerge (Crouch, 2009).

However, this inherently unstable transition era also led to the proliferation of some sensitive cases. Decentralization issued by President B. J. Habibie in Regional Government Act No. 22/1999 created many new administrative areas in Indonesia. Provinces, which initially numbered only 30 , were then expanded to become 33 . With this decentralization, the authority of local governments to issue regulations and policies that could be applied in the area was also introduced, these regulations were later referred to as regional regulations. The creation is similar to the creation of laws by the DPR and the President, just in a smaller scope, only at the Governor and DPRD levels.

Regional regulations are then made with a rationale that is based on the norms and socio-cultural conditions of the community (Sumaktoyo, 2020). This includes the role of religion, therefore, the revitalization of the role of religion at the legal and governmental levels is often carried out in several regions, some quite fundamental and strict - such as the Qanun in Aceh - due to lack of supervision and clear restrictions imposed by the central government.

Concerning religious life, the reform era began with several inter-religious skirmishes, the most severe of which was the sectarian conflict in Maluku between Muslims and Christians, even though this conflict was just a territorial dispute to decentralize governance on the islands of Maluku and Halmahera. Several sources also said that this conflict was driven by the separatist group of the Republic of South 
Maluku (RMS) which tried to undermine it again, seeing Indonesia's unstable condition and the end of the authoritarian New Order military regime (de Fretes, 1999).

In the following years, religious freedom continued to increase and decrease in contrast. Among these advances is included in the birth of Human Rights Act No. $39 / 1999$, in which its several articles support the existence of religious diversity in Indonesia, such as:

Article 4:

“... the right to freedom of person, thought and conscience, the right to religion ... are human rights that cannot be reduced under any circumstances and by anyone".

Article 22:

"Everyone is free to embrace their respective religions and to worship according to their religion and beliefs," and "The State guarantees the freedom of everyone to embrace their respective religions and to worship according to their religion and beliefs."

In 2000, the cancellation of Presidential Instruction No. 14/1967 concerning the Prohibition of Chinese Religions, Beliefs and Customs then restored the right of ethnic Chinese to be able to return to freedom of religious expression, they were free to worship and were free to celebrate their big days - a right that was deprived since 1967 (Muktiono, 2012).

However, several legal regulations were also created which later hindered religious freedom in Indonesia. About religious blasphemy, for example, this law was born in 1965 and has not been revoked or at least has undergone reform to make it more neutral and constitutional (Christianto, 2013). Some experts have now interpreted this law as unconstitutional and vulnerable to be used by the majority to discriminate against minorities (Kanas et al., 2015).

However, recently, cases of rejection of the establishment of places of worship, or vandalism against them have continued to occur in the current reformation period, sometimes accompanied by anti-tolerance sentiments that clearly violate layers of laws such as human rights and even the 1945 Constitution (Zaka Firma Aditya \& Al-Fatih, 2020), which very endangers the integration of this country as if it continues to mushroom and spread as if it were a pandemic. The SKB regulation which was updated in 2006 and re-published under the name PBM did not succeed in suppressing this case (Crouch, 2010), it can be seen from the many examples of cases so that problems regarding religious freedom during this reform period continued to decline and might lead to horizontal conflicts between religious communities.

\section{Regulation on Establishment of Religious Properties and Houses of Worship}

The existence of legal regulations in force in the religious sector does not exist without a concrete basis. The 1945 constitution which guarantees freedom of worship 
and religion is not present in the real implementation that exists in the conditions of community life. Meanwhile, several laws do not specifically solve particular problems that have not been resolved without a clearer legal provision.

The spiritual life of society with religious heterogeneity in it is a fragile fact because in it there are different teachings, these differences may trigger horizontal conflicts that will not be easy to resolve. The cases of disputes related to religious differences eventually gave birth to legal provisions governing the establishment of religious property and places of worship.

The earliest legal regulations issued in this sector were born as a solution offered by the government, at that time in the 1960s it was a transition period from the Old Order to the New Order. During the Old Order period, conflicts between religions were uncommon, but in the New Order, after anti-Communist sentiments arose which led to mass religious conversion to Christianity, discriminatory sentiments were born. It has been described in the previous chapter regarding real cases of disputes that arise because of this, namely:

a. Burning of an undung-undung (chapel) in Meulaboh, Aceh 1967;

b. Stone-throwing at a church in Makassar, South Sulawesi 1967;

c. Forced eviction of HKBP Slipi, West Jakarta 1969

These cases drew special government attention to the possible causes of these events. The government concluded that this happened because the construction or location of the place of worship was in the midst of a community of other religions. In the case of the burning of the Meulaboh Chapel, for example, the population of Christians in the area is very minimal, the village elders have warned of its existence, the local government has also suggested that the chapel be removed because it is not following the social conditions of the common people - who then think that the existence of a Chapel as an attempt by Christian missionaries who are trying to Christianize the area (Crouch, 2009).

Seeing this point of view, finally, the government through the minister of home affairs and the minister of religious affairs issued a joint decree (SKB) which contains regulations regarding the terms and conditions that must be met by a religious community in establishing a religious property or place of worship in a place. This regulation was initially considered positive because it was a real effort by the government in protecting the integration between interfaith communities which was in a critical period. This regulation was also a solution offered by the government in overcoming the problems that occurred and to prevent this incident from recurring for similar reasons.

It is humane if the proposed design is not following the plan, however in the creation of this regulation, the intention which was to prevent inter-religious conflicts, backfired becomes a means used by the majority to discriminate against minorities in the right to have a place of worship. The problems contained in this regulation are 
often used by the "particular" Muslim communities to justify their attacks or demonstrations in rejecting or vandalizing churches that they deem to be "located in Muslim area," and which are considered to have ulterior motives for Christianization (Adon, 2018).

This decree stipulates that the government is given the authority to supervise and ensure that places of worship are built without disturbing other religions, and that violations against them can be reported by civilians who witness them (Hutabarat, 2017). The defects contained in this decree create many problems of discrimination and intolerance, which indirectly also threaten the unity and integrity of the nation. This regulation underwent reform in 2006, with results that were not much different, in fact, it only slightly increased the difficulty of licensing the construction of houses of worship, the regulation was re-published as PBM No. 9 and 8 of 2006, although the goals of the reform are to minimalize the issue, it misfit in the term of maintaining equality (Pangestu, 2013).

The PBM was issued to complement some particular things that are not regulated in the previous version of the regulation (SKB). Some of the special regulations contained in this PBM include requiring the conformity of building functions with what is stated in the land certificate and Building Construction Permit (IMB), making the conversion of a building into a place of worship very difficult. Also, the conversion of the building function to become a place of worship, or the construction of a new place of worship must obtain the approval of at least 60 residents with an active Identity Card - also the approval of the 90 congregation members if the designated place of worship is a church.

In another aspect, the failure of this regulation is due to it was not implemented successfully, because parties who would ask for permission would usually be faced with an awkward position. If the party did what the regulation requested accordingly (asked for approval manually from 60 residents), not only would it take a long time and the expected approval could not be obtained because of the suspicion. Meanwhile, if it is carried out through certain "officers" who are more time-efficient, it will usually lead to mass demonstrations under the auspices of certain community organizations that call the construction of places of worship illegal (Crysdian, 2015).

Even when applications for establishment activities are official and permitted both by the government and by residents under the criteria required by PBM to build places of worship, demonstrations often occur by residents - who are not even residents, but because of the connection of one religious organization which rejects the construction of these places of worship - and even some acts of anarchism such as vandalism, looting, and even evictions. These problems are occurring with or without the issuance of the PBM. In some of the cases listed, it can be seen that the gap in the shortcomings of this PBM is also used as a way to make it difficult, cancel or prevent the establishment of places of worship_especially for religious minorities—also indirectly 
injures the right to freedom to practice religion according to beliefs as contained in the provisions of the constitution.

It is indeed a task for the government to reform a new legal regulation that is equal and does not have the opportunity to be used as material to attack other religious communities in a discriminatory manner (Steven et al., 2015). But more importantly, it is to carry out optimal education and form citizens who are willing to live in conditions of coexistence. Infatuated with tolerance and respect for differences.

\section{Infringement on Human Rights and Legal Failure to prevent it}

The Indonesian government has done with all its efforts to facilitate and accommodate the diversity of the heterogeneity of religious communities In Indonesia. It is instilled in the country's slogan Bhinneka Tunggal Ika, (Unity in Diversity). Various state attributes are also made by prioritizing unity and nondiscriminatory aspects, Pancasila for example, calls "Belief in One True God," as its first point - which is neutral from any particular religious influence, but still concludes that belief in God is the basis the state - besides that, the 1945 constitution also mentions a lot about freedom of religion and worship, referring to it as part of human rights, which are highly respected in the Republic of Indonesia.

The prohibition and adversity for establishing places of worship have an impact on the implementation of worship activities. Meanwhile, the 1945 constitution guarantees freedom of religious adherence and the implementation of all religious activities. By stating that: Article 28I p. (1) 1945 Constitution "Right to adhere to a religion is a part of Human Rights”

And regarding the mention and reference to Human Rights, Indonesia is one of the countries that has participated in ratifying UDHR in the Human Rights Act No. 39/1999. Which in terms of relation to the practice of religion, Article 22 states "Everyone is free to embrace their respective religions and to worship according to their religion and beliefs", and "The State guarantees the freedom of everyone to embrace their respective religions and to worship according to their religion and beliefs."

Recognition and protection of human rights in Indonesia covers a very broad scope, and specifically in religious matters, this field has received a legal status that is continually strengthened by the existence of guarantees at the juridical-constitutional level (Asy'ari, 2013). This is evidenced by the many mentions of "freedom of religion" in various existing laws and regulations. In the 1945 Constitution itself, for example, freedom of religion is mentioned in various Articles 28E, and 29 are the examples: Article 28E p. (1) 1945 Constitution: "Every person is free to adhere to a religion and worship accordingly to their religion...". Article 28E p. (2) 1945 Constitution: "Every person has right to freedom of beliefs". Article 29 p. (2) 1945 Constitution: "The State guaranteed the freedom of religious beliefs for each of its citizens." 
As a consequence of the stated religious freedom, rights in worship and belief in belief should be protected by a constitution that protects personal rights, property, guarantees of the right to security, protection from fear, and the right to be free from torture or treatment that degraded any part of human dignity (Pratiwi, 2019). Therefore, any activities that state a prohibition or obstruction in the construction of places of worship are in absolute violation of the Human Rights Act No.39 of 1999 in terms of "freedom to worship according to the teachings of their respective religions".

In the 2014-2018 period alone, there were 488 cases relating to rejection and also vandalism against buildings of places of worship, all of which have the status of minority houses of worship in the majority religious community. These recent cases occurred to various religious minorities in a region (Situmorang, 2019), such as:

a. Attack on St. Lidwina Catholic Church, Yogyakarta,

b. Disbandment of Gafatar, Kalimantan,

c. Attacks and vandalism to religious properties and expulsion of Ahmadiyya

followers, East Lombok

d. Destruction of Viharas and Lithang in Tanjung Balai, Medan.

e. Demonstrations and Rejection of the Establishment of St. Stanislaus' Catholic

Church in Jatisampurna, Bekasi

f. The burning of Mosque and Houses in Tolikara, Papua.

g. The burning of Shi'ite boarding school and Mosque in Sampang, Madura

Looking further back, there have been several rejections and even annulment of church construction permits, such as in the cases of GKI Yasmin and HKBP Filadelfia which had been busy in the media both within the country and abroad. The cases that can be categorized as pure discrimination and intolerance were born from the PBM which regulates the construction of places of worship (Crouch, 2009).

It is the provisions in the regulation that are then used as a tool to refuse the establishment of a place of worship on the pretext of fraud by the petitioner is asking for public approval or Incompatibility of the construction of places of worship with the number of adherents of that religion in the surrounding area. These things happen even when the permits and requirements are met. Like the demonstration that was carried out on the Church of St. Stanislaus, Jatisampurna, which is the refusal of residents from other areas to projects licensed by the government and approved by residents. Then the burning of the workers' lodgment who were building the Church of St. Albert in Harapan Indah, this tragedy was also accompanied by the looting of building materials. The government's efforts to enforce human rights law seem to have faded with this PBM decree. Indeed, the right in the implementation of religion is a derogable right, the implementation of which can be limited under the prevailing conditions in a country. However, various restrictions and violations including sealing, arson, attacks in the name of religion are violations of human rights as contained in Article 18 paragraph (3) of the International Covenant on Civil and Political Rights (ICCPR). 
Particularly related to the construction of places of worship which is a manifestation of the practice of belief (Putri, 2011) —a fundamental elemental right that is sacred and should not coincide with the practice of religious freedom.

\section{CONCLUSION}

This paper highlighted and concluded that the diversity of religious communities and freedom of religion in Indonesia has been protected in the 1945 Constitution. This diversity will continue to be a scourge for the nation's socio-political integration. Several cases of refusal of construction and vandalism in places of worship indeed have violated the 1945 Constitution, Fundamental Human Rights, as well as International Conventions concerning Human Rights. Apart from threatening national integration, these discriminatory acts violate human rights, which are also protected and guaranteed in Human Rights Act No. 39 of 1999. The SKB regulation for the place of worship establishment policy has different translations and interpretations, both between community leaders and certain community groups so that this creates further conflict in society. Although in some cases restrictions on freedom of religion are permitted, however, special rules are very needed concerning the construction of places of worship so that they have a clear legal basis and are nationally binding. Furthermore, this paper also concluded that cross-sectoral cooperation is needed in overcoming inter-religious conflicts, especially in several regions in Indonesia.

\section{REFERENCES}

Aditya, Z., \& Al-Fatih, S. (2017). State Liability for Violation of Constitutional Rights Against Indigenous People in Freedom of Religion and Belief. Brawijaya Law Journal, 4(1), 29-58. https://doi.org/10.21776/ub.blj.2017.004.01.02

Aditya, Z Firma, \& Al-Fatih, S. (2017). Democracy and Human Rights As A Solution To Resolve The Humanitarian Crisis In Muslim Countries. Conference On Islamic Studies (ICIS).

Aditya, Zaka Firma, \& Al-Fatih, S. (2020). Indonesian constitutional rights: expressing and purposing opinions on the internet. International Journal of Human Rights, O(0), 1-25. https://doi.org/10.1080/13642987.2020.1826450

Adon, N. J. (2018). Konflik dan integrasi pendirian rumah ibadah di kota bekasi. Socio-Politica, 8(2), 227-238.

Ali, M. I. (2020). Comparative Legal Research-Building a Legal Attitude for a Transnational World. Journal of Legal Studies, 26(40), 66-80. https://doi.org/10.2478/jles-2020-0012

Ali, S., Mohamed Yusoff, Z., \& Ayub, Z. (2017). Legal Research of Doctrinal and Non-Doctrinal. International Journal of Trend in Research and Development, 4(1), 493 495.

Asy'ari, H. (2013). Politik Hukum Kebebasan Beragama di Indonesia. Pandecta: Research Law Journal, 6(1). https://doi.org/10.15294/pandecta.v6i1.2319

Basyir, A. A. (1993). Hukum Islam Di Indonesia dari Masa ke Masa. Unisia, 13(16), 9-13. https://doi.org/10.20885/unisia.vol13.iss16.art1 
Blussé, L. (2016). Batavia, 1619-1740 : The Rise and Fall of a Chinese Colonial Town. Journal of Southeast Asian Studies, 12(1), 159-178.

Bowen, J. R. (2010). Religious discrimination and religious governance across secular and islamic countries: France and indonesia as limiting cases. American Behavioral Scientist, 53(12), 1749-1762. https://doi.org/10.1177/0002764210368095

Christianto, H. (2013). The Significant Impact of Law Number 1 / PNPS / 1965. Jurnal Yudisial, 6(1), 1-16.

Crouch, M. (2009). Religious regulations in Indonesia: failing vulnerable groups. Review of Indonesian and Malaysian Affairs, 43(2), 53-103.

Crouch, M. (2010). Implementing the regulation on places of worship in Indonesia: New problems, local politics and court action. Asian Studies Review, 34(4), 403419. https://doi.org/10.1080/10357823.2010.527921

Crysdian, C. (2015). Strategy to Develop Geospatial Analysis to Govern the Problem of Public Places of Worships in Indonesia. Australian Journal of Basic and Applied Sciences, 9(7), 172-175.

de Fretes, C. H. J. (1999). DINAMIKA ISU REPUBLIK MALUKU SELATAN ( RMS ) TERHADAP MASYARAKAT AMBON DALAM KONFLIK 1999 Oleh : Jurnal Penelitian Sosial Cakrawala, 5(1), 45-68.

Hamayotsu, K. (2013). The Limits of Civil Society in Democratic Indonesia: Media Freedom and Religious Intolerance. Journal of Contemporary Asia, 43(4), 658-677. https://doi.org/10.1080/00472336.2013.780471

Haris, M. (2017). Warisan Paradigmatik Kebijakan Politik Kerukunan Antaragama Kolonial Pada Masa Reformasi. Tasamub: Jurnal Studi Islam, 9(1), 157-208.

Hartani, M., \& Nulhaqim, S. A. (2020). Analisis Konflik Antar Umat Beragama Di Aceh Singkil. Jurnal Kolaborasi Resolusi Konflik, 2(2), 93. https://doi.org/10.24198/jkrk.v2i2.28154

Hefner, R. W. (2013). the Study of Religious Freedom in Indonesia. Review of Faith and International Affairs, 11(2), 18-27. https://doi.org/10.1080/15570274.2013.808038

Heidhues, M. S. (2012). Anti-Chinese violence in Java during the Indonesian Revolution, 1945-49. Journal of Genocide Research, 14(3-4), 381-401. https://doi.org/10.1080/14623528.2012.719371

Hutabarat, B. A. (2017). Evaluasi terhadap Peraturan Bersama Menteri Tahun 2006 tentang Pendirian Rumah Ibadah. Societas Dei: Jurnal Agama Dan Masyarakat, 4(1), 8. https://doi.org/10.33550/sd.v4i1.41

Islam, M. H. (2020). Tolerance Limitation in Facing Religious Diversity Based on the Teaching of Islam. Nąhruna: Jurnal Pendidikan Islam, 3(1), 1-13. https://doi.org/10.31538/nzh.v3i1.483

Kanas, A., Scheepers, P., \& Sterkens, C. (2015). Interreligious Contact, Perceived Group Threat, and Perceived Discrimination: Predicting Negative Attitudes among Religious Minorities and Majorities in Indonesia. Social Psychology Quarterly, 78(2), 102-126. https://doi.org/10.1177/0190272514564790

Kim, H. J. (1998). The changing interpretation of religious freedom in Indonesia. Journal of Southeast Asian Studies, 29(2), 357-373. https://doi.org/10.1017/s0022463400007499

Marshall, P. (2018). The Ambiguities of Religious Freedom in Indonesia. Review of 
Faith and International Affairs, 16(1), 85-96.

https://doi.org/10.1080/15570274.2018.1433588

McConville, M. (2017). Research Methods for Law (M. McConville (Ed.)). Edinburgh University Press.

Mu'ti, A., \& Burhani, A. N. (2019). The limits of religious freedom in Indonesia: with reference to the first pillar Ketuhanan Yang Maha Esa of Pancasila. Indonesian Journal of Islam and Muslim Societies, 9(1), 1-29. https://doi.org/10.18326/ijims.v9i1

Muchtar, I. H., Khalikin, A., Syaukani, I., Mubarok, H., Nuh, N. M., Haryanto, J. T., \& Hakim, B. A. (2010). Dilema Pendirian Rumah Ibadat dan Keragaman Faham Keagamaan. HARMONI - Jurnal Multikultural Dan Multireligius, IX(September), $1-263$.

Muktiono. (2012). Mengkaji Politik Hukum Kebebasan Beragama Dan Berkeyakinan Di Indonesia. Jurnal Dinamika Hukum, 12(2).

https://doi.org/10.20884/1.jdh.2012.12.2.59

Pangestu, O. S. (2013). Efektivitas Pasal 14 Peraturan Bersama Menteri Agama Dan Menteri Dalam Negeri Nomor 9 Tahun 2006/ Nomor 8 Tahun 2006 Tentang Pedoman Pelaksanaan Tugas Kepala Daerah/Wakil Kepala Daerah Dalam Pemeliharaan Kerukunan Umat Beragama, Pemberdayaan Forum Kerukun. Kumpulan Jurnal Mahasiswa Fakultas Hukum, 1(1), 1-35.

Pratiwi, C. S. (2019). Rekonstruksi Hukum Ham Nasional Sebagai Upaya Mencegah Pengulangan Pelanggaran Hak Kebebasan Beragama Dan Berkeyakinan (KBB). The Institute of Human Rights and Peace Studies.

Putri, N. S. (2011). Pelaksanaan Kebebasan Beragama Di Indonesia (External Freedom) Dihubungkan Ijin Pembangunan Rumah Ibadah. Jurnal Dinamika Hukum, 11(2). https://doi.org/10.20884/1.jdh.2011.11.2.183

Rotaru, I.-G. (2017). Freedom of Religion, Always a Hot Issue. Jurnalul Libertătii de Conștiință, 5(1), 545-550.

Seo, M. (2012). Defining "religious" in Indonesia: Toward neither an Islamic nor a secular state. Citizenship Studies, 16(8), 1045-1058. https://doi.org/10.1080/13621025.2012.735028

Situmorang, V. H. (2019). Kebebasan Beragama Sebagai Bagian dari Hak Asasi Manusia. Jurnal HAM, 10(1), 57. https://doi.org/10.30641/ham.2019.10.57-67

Steven, A., Gumansalangi, A. G., \& Prasetiyawati, Y. E. (2015). Urgensi Pembaharuan Regulasi Pendirian Rumah Ibadah di Indonesia. Jurnal Sapientia et Virtus, 2(1), 15-25.

Sumaktoyo, N. G. (2020). A Price for Democracy? Religious Legislation and Religious Discrimination in Post-Soeharto Indonesia. Bulletin of Indonesian Economic Studies, 56(1), 23-42. https://doi.org/10.1080/00074918.2019.1661354

Van Hoecke, M. (2016). Methodology of Comparative Legal Research. Law and Method. https://doi.org/10.5553/rem/.000010

Wahyudi, A. T. (2016). Kewenangan Absolut Peradilan Agama di Indonesia pada masa Kolonial Belanda hingga Masa Pasca Reformasi. Yudisia, 7(2), 285-304. https://doi.org/10.21043/yudisia.v7i2.2156

Watkins, D., \& Burton, M. (Eds.). (2017). Research Methods in Law. Routledge.

Wijayanto, E., Halim, W., \& Tobroni, F. (2020). Perdamaian Gejolak Pencabutan 
Izin Rumah Ibadah Di Bantul. TAS AMUH: Jurnal Studi Islam, 12(2), 373-390. https://doi.org/10.47945/tasamuh.v12i2.246 